\title{
The Effect of Communication and Immigration Activities in 7th Grade Social Studies Course on the Empathy Skills of Students
}

\author{
Birol Bulut ${ }^{1}$, Süleyman Aslan ${ }^{1}$ \\ ${ }^{1}$ Faculty of Education, Firat University, Elazig, Turkey \\ Correspondence: Birol Bulut, Faculty of Education, Firat University, 23190, Elazig, Turkey.
}

Received: February 21, 2019

Accepted: March 11, 2019

Online Published: April 22, 2019

doi:10.11114/jets.v7i5.4224

URL: https://doi.org/10.11114/jets.v7i5.4224

\begin{abstract}
The feeling of empathy is as old as the humankind. Empathy is an attempt to perceive the emotions and to understand the thoughts of other individuals and discern their point of view. Due to such aspects, empathy presents "a focus on other individuals". In general terms, empathy was defined as "adopting a sensitive attitude towards correctly understanding the emotions and thoughts of another individual, encountering any event, through placing oneself in the place of that individual during the process of communication."

The present study was intended to determine the effects of the communication and immigration subjects in the 7th grade social studies course on the empathy skills of students through employing the didactic approach, which is one of the techniques for empathy development.

Concurrent nested (embedded) design, a mixed research method, was employed in the present study. Mixed-method research is defined as the approach through which the researcher draws conclusions by using the advantage of integrating qualitative and quantitative methods, approaches and concepts in a study or consecutive studies with the aim to understand diverse research models. The quantitative data in the present study were obtained via the "Index of Empathy for Children and Adolescents", whereas the qualitative data were collected through interview forms.

Almost all students emphasized the significance of empathy and understanding the feelings of the migrants for understanding the causes and consequences of immigration throughout the activities related to immigration.
\end{abstract}

Keywords: social studies, empathy, communication

\section{Introduction}

\subsection{Empathy}

Feeling of empathy is an important concept as old as the humankind and is even defined as the basis of good social relations. Several studies were conducted on the concept of empathy and various definitions were formulated by these studies. Concepts of empathy and empathy skills became an integral part of educational sciences, due to the strong emphasis that it was possible to teach these frequently studied concepts.

Empathy is an important social skill that allows individuals to view and understand the perspectives of other individuals. The ability to empathize stems from the acknowledgement and recognition that other individuals have identities, different values and beliefs (Yüksel, 2015). Contemporary approaches define empathy as the social interaction between two individuals, where an individual experiences the feelings of another individual (Feshbach \& Feshbach, 2009). Empathy is to perceive another individual's feelings and thoughts as his/her and to place him/herself in the place of the other individual (Rogers, 1962, as cited in Alver, 2005). Dokmen (1998) defined empathy as perceiving events from another individual's point of view, correctly understanding, feeling and communicating this feeling to that individual through placing oneself in the circumstances of that individual. According to Halpern (2003), empathy is a skill learned to understand and communicate with other individuals.

Studies conducted on empathy provided several findings regarding the necessity and importance of empathy skills. Particularly, studies concluded that empathy skills were teachable and that existed as a basic condition for effective communication in interpersonal relations. It was determined that the personal characteristics, social cohesion and collaboration-assistance tendencies of children with high empathy skills were more positive when compared to children with low empathy skills. Moreover, it was established that the empathy skill levels of children with high levels of 
aggression were low, in other words, there was an inverse relationship between aggression and empathy skills (Yüksel, 2004; Barrachlough, 2000; Otfinowski, 2000; Roberts \& Strayer, 1996; Öz, 1992; Eisenberg \& Fabes, 1990; Bilbery, 1990; Cottle,1987; Feschbach, 1982; Pruden,1976). Furthermore, individuals with high empathy skills were found to have a positive psychological development (Kalliopuska, 1992). People with high empathy skills were found to be more successful in perceiving what other individuals want and need (Leiberg \& Anders, 2006).

The aim of empathy training is to develop the ability of empathy that exists in humans and thus, to help individuals build healthy interpersonal relationships with other individuals. In order to realize such objective, researchers developed various structured programs, with the name, empathy training programs. It was observed that the educational programs prepared to develop empathy skills of individuals focus on developing emotional and cognitive abilities including the empathy response. Furthermore, these programs include cognitive elements such as recognizing, evaluating and identifying emotions required when empathizing (Yüksel, 2004). According to Unal (2007, p. 145), parents and educators should be good role models for the children through being empathetic towards them and putting the words into action. Establishing a relationship of love and trust with children, expressing that they understand and feel the children through identifying and acknowledging their emotions, talking about the impact of their behavior on others, talking about what others feel about them, ensuring that children focus on the similarities between oneself and other individuals, approving the differences between other individuals and supporting children to accept and trust other individuals are further significant factors in the development of empathy skills in children.

Brems (1988) emphasized that empathy was composed of affective and cognitive dimensions. Brems also emphasized that understanding the feelings and thoughts of another individual was the cognitive aspect of empathy and feeling like the other individual was the affective aspect of empathy. While the cognitive dimension, which is more complex, requires mentally understanding another individual through not being self-centered, the developmentally lower affective dimension involves accurate understanding of the feelings of the other individual, regardless of self-centeredness or the cognitive structure of the response.

Dökmen (1988) proposed approaches such as didactic training technique, model learning technique, experiential education technique and role-playing technique for empathy training. The present study was intended to implement the didactic approach in a holistic manner to develop the empathy skills through the subjects of communication and immigration in the 7 th grade social studies course.

It was ensured that the students realized why an immigrant left his/her hometown and went to another country through placing themselves in their place to understand their emotions and thoughts. In this respect, it was established that the course objectives were not only cognitive but also affective. In the present research, it was aimed to clarify the communication and immigration issues through providing theoretical information on healthy communication and empathy with individuals, employing the "didactic training technique" in the 7th grade social studies course and to examine the effects of this process on the students' empathy skills.

\subsection{Application}

Two study groups, the experiment and the control, were determined in order to compare the outcomes of the present study. The control group continued to receive the standard course structure. For the experiment group, an approach that integrated the subjects of "communication" and "immigration", 10 course-hour subjects in the 7th Grade Social Studies Course Plan, with the didactic approach that aims to provide empathy skills was adopted and the affective goals were determined. Before initiating the application, the "Index of Empathy for Children and Adolescents", developed by Bryant (1982) and adapted to Turkish by Gürtunca (2013), was applied to both groups as the quantitative data collection tool. The teacher provided information on the definition and importance of the concept of empathy before starting the lecture and subsequently the subjects were taught through explaining the concepts that facilitated the comprehension of the concept of empathy. As the application was completed both groups were given the "Index of Empathy for Children and Adolescents" once more and the findings were analyzed.

Subsequent to the application, the questionnaire, designated as the other data collection tool, was submitted to the experimental group students and the students were asked questions regarding the concept of empathy, change of behavior and how they understood the feelings of other individuals.

\section{Method}

Concurrent nested (embedded) design, a mixed research method, was employed in the present study. Mixed-method research is defined as the approach through which the researcher draws conclusions by using the advantage of integrating qualitative and quantitative methods, approaches and concepts in a study or consecutive studies with the aim to understand diverse research models (Creswell, Sözbilir, 2017; Tashakkori and Teddlie, 1998; Johnson and Onwuegbuzie, 2004). One of the reasons for using the mixed research approach in the present study was to provide a 
better understanding of the research topic. Thus, it would be possible to reach to more effective and comprehensive conclusions through examining the subject in more detail and in depth.

\subsection{Study Group}

The study group was composed of 37 students in the experiment group and 38 students in the control group, studying at a secondary school affiliated with the Ministry of Education, in Diyarbakır, Turkey.

\subsection{Data Collection Tools}

The "Index of Empathy for Children and Adolescents", developed by Bryant (1982) and adapted to Turkish by Gürtunca (2013), was utilized as the quantitative data collection tool. The scale consists of 22 items and is a paper-pen scale to be used with children and adolescents. Children respond to the items in the scale in the form of yes or no, based on the meaning items express for them. For the two-point response format, the item scores in the scale are between 0 and 1 . The total score that could be received from the two-point response format vary between 0 and 22 . The obtained Cronbach alpha internal consistency coefficients were determined as $r=0.74$ in the first grades, $r=0.81$ in the fourth grades and r=0.83 in the seventh grades (Gürtunca, 2013, p.69).

Semi-structured interview forms were used as the qualitative data collection tool. In this technique, the researcher prepares the interview forms containing the questions he/she intends to ask and change the interview structure with different side- or sub-questions depending on the flow of the interview (Ekiz, 2003). The semi-structured interview form was developed based on 4 research questions.

\section{Results}

\subsection{Findings}

The present section includes the findings and comments obtained during the research process.

Table 1. t-Test Results for the Comparison of Pre-test Empathy Levels between Groups

\begin{tabular}{lllllll}
\hline Group & $\mathrm{N}$ & $\overline{\boldsymbol{X}}$ & $\mathrm{Sd}$ & $\mathrm{t}$ & $\mathrm{df}$ & $\mathrm{p}$ \\
\hline Pre-Test Scores for the Experiment Group & 38 & 11,62 & 2,77 & 1,36 & 73 &, 635 \\
& & & & & & \\
Pre-Test Scores for the Control Group & 37 & 12,18 & 2,29 & & & \\
\hline
\end{tabular}

The findings presented in Table 1 indicated that the average empathy levels of groups were close based on the pre-test results. There was no evidence that such close results also yielded a statistical significance (p>,05). Therefore, it was possible to state that there was a balance between the groups.

Table 2. t-Test Results for the Comparison of Post-test Empathy Levels between the Experiment and Control Groups

\begin{tabular}{llrllll}
\hline Group & $\mathrm{N}$ & $\overline{\boldsymbol{X}}$ & $\mathrm{Sd}$ & $\mathrm{t}$ & $\mathrm{df}$ & $\mathrm{p}$ \\
\hline Pre-Test Scores for the Experiment Group & 38 & 13,52 & 3,30 & 1,88 & 68 &, 107 \\
& & & & & & \\
Pre-Test Scores for the Control Group & 37 & 12,23 & 2,17 & & & \\
\hline
\end{tabular}

Table 2 indicates that the mean empathy scores differed slightly in favor of the experimental group based on the post-test results of the groups. There was no evidence that this difference was statistically significant ( $p>, 05)$.

The other data collection tool utilized in the study was the interview forms. The interview forms were intended to gather information on the concept of empathy, change in behavior and thoughts due to the application.

Findings on the Definition of the Empathy Concept

Once the students' views on the concept of empathy were evaluated, it was observed that there were 4 sub-themes that defined the concept of empathy. The views on the concept of empathy were presented below.

Table 3 The views on the concept of empathy

\begin{tabular}{ll}
\hline Views & Frequency \\
\hline Placing ourselves in the place of others and understanding them & 16 \\
Collaboration and assistance & 14 \\
Communicating & 5 \\
Socializing & 5 \\
\hline
\end{tabular}




\section{Example Expressions:}

S3: Questioning what we would think if we experienced the event that our friend experienced.

S5: ... Understanding people, recognizing them and to approach events thinking like them.

S7: Communicating with people, understanding them and being a social person...

S11: ... Thinking about what and how others think without being self-centered.

S16: Most of the time we don't care about others, we only think about ourselves, but if we empathize, we also think about others. Sometimes we think like others.

S20: Looking at an event from the viewpoint of other people...

Another question asked the students was related to whether there was a change in their behavior towards their friends after the practice. The obtained data were classified under 3 sub-themes.

Table 4. Views on the Behavior Change after the Application

\begin{tabular}{ll}
\hline Views & Frequency \\
\hline I had a change in behavior & 20 \\
I had a partial change in behavior & 7 \\
I had no change in behavior & 5 \\
\hline
\end{tabular}

Example Expressions:

S2: Yes, I had a change because my thoughts changed after our teacher informed us about empathy.

S9: I started to have a better communication with my friends after this course, my behavior towards them changed.

S19: Yes, because I realized that I have to be a good person.

S27: There was not much change because I already listen to my friends, only I liked hearing that this is a good thing.

S15: No, I was bored of the course.

Another question the students were asked was "how they understood someone was happy or sad". Three sub-themes emerged due to the categorization of the responses to this question. These sub-themes were presented in Table 5.

Table 5. Views on How to Understand the Sadness and Happiness of Others

\begin{tabular}{ll}
\hline Views & Frequency \\
\hline Facial expressions & 20 \\
Tone of the voice & 17 \\
I don't really understand & 9 \\
\hline
\end{tabular}

Example Expressions:

S7: I usually understand from their facial expressions and tone of voice.

S9: If my friend is not someone who hides his emotions, I understand it from his face, voice and behavior.

S15: Face shows the feelings of every human being. Because a person's face is the mirror of that person.

Another question the students were asked was "their thoughts on immigrants". Three sub-themes emerged due to the categorization of the responses to this question. These sub-themes are provided in Table 6.

Table 6. Views on Immigrants

\begin{tabular}{ll}
\hline Views & Frequency \\
\hline My thoughts on immigrants changed in a positive way & 19 \\
My thoughts on immigrants did not change & 15 \\
\hline
\end{tabular}

Example Expressions:

S11: I was angry with immigrants before. Because I thought they caused unrest in places they go. I was especially prejudiced against those coming from Syria to our country. But now I don't think that anyone will leave their country unless they have to. I understand them better.

S14: I understand better that it is not good to judge immigrants without understanding the reasons that forced people to immigrate. 
S21: I never considered immigrating, and I still don't understand the immigrants.

S32: I have always been moderate towards immigrants.

\section{Conclusion, Discussion and Suggestions}

In the present study, the aim was to increase the empathy levels of students by integrating empathy training with the subjects of "Communication and Immigration" in 7th grade social studies course. Before initiating the application, the "Index of Empathy for Children and Adolescents", developed by Bryant (1982) and adapted to Turkish by Gürtunca (2013), was applied to both groups as the pre-test. The data obtained from the scale, applied both the experiment and control groups, indicated that the empathy levels of both groups were close, and the results of the experiment group was slightly lower (Experiment group $\mathrm{X}^{\overline{:}}: 11,62$; Experiment group $\mathrm{X}^{-}: 12,18$ ).

Once the 10 course-hour subjects "Communication" and "Immigration" within the social studies curriculum were completed the empathy scale was once more submitted to the experiment and control groups. The examination of the data of the post-test indicated that the empathy scores of the experiment group increased and the average scores of the control group for the empathy scale increased only slightly. However, t-test analysis conducted with SPSS 21 did not provide any evidence that the differences of scores were statistically significant (Experiment group $\mathrm{X}^{-}: 13,52$; Control group $\mathrm{X}^{-}$:12,23).

Subsequent to the application, the views of the students in the experiment group students were received via the interview forms, which were the qualitative data collection tools. The first question the students were asked was on the concept of empathy. The majority of students defined the concept of empathy as identifying oneself with others to understand them, collaboration and assistance and communicating. Another question the students were asked was related to the change they experienced in own behavior towards their friends after the application. The majority of the students were interested in communicating better with their friends and understanding them better. Another question the students were asked was "how they understood someone was happy or sad". The responses to this question were related to the fact that they understandood if someone was happy or sad was through the facial expressions and tone of voice. The last question students were asked was intended to understand what the students thought about immigrants. Particularly after the application, the students stated that they empathized with immigrants, they understood them better and they intended to understand why they had to immigrate.

As a result, integrating the communication and immigration issues with the methods that develop empathy skills resulted with an increase in empathy skill levels of the experiment group. Although such increase was not statistically significant, it provided particular concrete results that it could be an effective method due to several changes and developments in the application process and that empathy could be taught. Previous studies already emphasized that empathy skills could be learned. Halpern (2003) describes empathy as a learned skill for understanding and communicating with other individuals. Therefore, educational programs and teaching environments are significant for an individual to develop empathic behaviors. Clearly, educational programs alone do not provide sufficient means to gain empathy skills. Teachers and parents should be good role models for the children through being empathetic to them and putting the words into action (Unal, 2007).

Suggestions:

- Teachers and educational institutions should frequently utilize empathy training methods to help deliver and develop empathy skills.

- The subjects which are included in the curriculums and which are considered helpful for the development of empathic behaviors should be taught integrated with the empathy training methods.

- It is essential to deliver empathic behavior skills through social clubs and community service practices.

- Class management should contribute to delivering empathy skills.

- The skill of understanding more individuals should be endorsed through increasing the communication and socialization opportunities of students.

\section{References}

Alver, B. (2005). Psikolojik Danışma Ve Rehberlik Eğitimi Alan Öğrencelerinin Empatik Beceri Ve Karar Verme Stratejilerinin Çeşitli Değişkenlere Göre İncelenmesi, Muğla University, Journal Of Social Sciences And Humanities Researches, 15, 19-34.

Barraclough, D. J. (2000) Changes In Counselor Intentions After Empathy Training (Phd Dissertation,) The University Of North Dakota, Retrieved Jun, 2018. Web: Http/:Www.Umi.Com/Dissertations.

Bilbery, G. D. (1990) The Effects Of Computer Client- Simulation Training On Two Measures Of Empathy. 
Dissertation Abstracts International. 50/ 08.

Brems, C. (1988). Dimensionality Of Empathy And Its Correlates. The Journal Of Psychology, 123(4), $329-337$. Https://Doi.Org/10.1080/00223980.1989.10542989

Cottle, L. (1987). Effects Of Four Training Conditions Upon Married Couples Empathic Ability, Perception Of Spouse's Empath, Marital Intimacy And Marital Satisfaction, Dissertation Abstracts International, 49, 746A.

Dökmen, Ü. (1988). Empatinin Bir Modele Dayandırılarak ÖlçÜLmesi Ve Psikodrama Ile Geliştirilmesi, Ankara University Journal Of Faculty Of Educational Sciences (JFES), 62(21), 155-190.

Eisenberg, N., \& Fabes R. (1990) Empathy: Conceptualization, Measurement And Relation To Prosocial Behavior, Motivation And Emotion, 14, 131-149. Https://Doi.Org/10.1007/BF00991640

Ekiz, D. (2003). Eğitimde Araştırma Yöntem Ve Metotlarına Giriş. Ankara.

Feshbach, N. D. (1982). Sex Differences In Empathy. In N. Eisenberg (Ed.) The Development Of Prosocial Behavior, New York: Academic Press. Https://Doi.Org/10.1016/B978-0-12-234980-5.50017-1

Feshbach, N. D., \& Feshbach, S. (2009). Empathy And Education, Jean Decety \& William Ickes (Ed.), The Social Neuroscience, A Bradford Book, The MIT Press, England.

GÜRtunca, A. (2013). Çocuklar Ve Ergenler İçin Empati Ölçeği TÜRkiye Geçerlik Ve GÜVenirlik Çalışması (Dissertation), Institute Of Social Sciences, İstanbul Arel University, İstanbul.

Halpern, J. (2003). What Is Clinical Empathy? Journal Of General Internal Medicine, 18, $670-674$. Https://Doi.Org/10.1046/J.1525-1497.2003.21017.X

Kalliopuska, M. (1992). Holistic Empathy Education Among Pre-School And School Children, Paper Present At The International Scientific Conference Comenius Heritage And Education Of Man. London: Garland Publishing.

Leiberg, S., \& Anders, S. (2006). The Multiple Facets Of Empathy: A Survey Of Theory And Evidence. Progress In Brain Research, 156, 419-440. Https://Doi.Org/10.1016/S0079-6123(06)56023-6

Otfinowski, G. A. (2000). Effects Of Empathy Training On The Peer Approval Of Third Graders, (Phd Dissertation), University Of San Francisco.

Öz, F. (1992). Hemşirelerin Empatik İletişim Becerisi Ve Eğitimin Etkisi, (Phd Thesis), Health Sciences Institute, Hacettepe University, Ankara.

Pruden, C. W. (1976). The Effects Of Role Playing And Trainee Feedback In The Development Of Selected Facilitative Skills, Dissertation Abstract International, 37, 4142-4143.

Roberts, W., \& Strayer, J. (1996) Empathy, Emotional Expressiveness And Prosocial Behavior Child Development, 67, 449-470. Https://Doi.Org/10.2307/1131826

Rogers, C. R. (1962). The Interpersonal Relationship: The Core Of Guidance, Harvard Educational Review, 32(4).

ÜNal, F. (2007). Çocuklarda Empatinin Gelişimi: Empatinin Gelişiminde Anne-Baba Tutumlarının Etkisi. Journal Of National Education, 176.

YÜKsel, A. (2004). Empati Eğitim Programının İlköğretim Öğrencilerinin Empatik Becerilerine Etkisi, Journal Of Uludağ University Faculty Of Education, 17(2), 341-354.

YÜKsel, A. (2015). Empati: Tanım, Kapsam, Oluşum Ve Gelişim, YÜCel Kabapınar, (Ed.) Empatiyle Gelişmek, Empatiyi Geliştirmek: Çocuk Ve Empati, Pegem Akademi Publications, Ankara

\section{Copyrights}

Copyright for this article is retained by the author(s), with first publication rights granted to the journal.

This is an open-access article distributed under the terms and conditions of the Creative Commons Attribution license which permits unrestricted use, distribution, and reproduction in any medium, provided the original work is properly cited. 